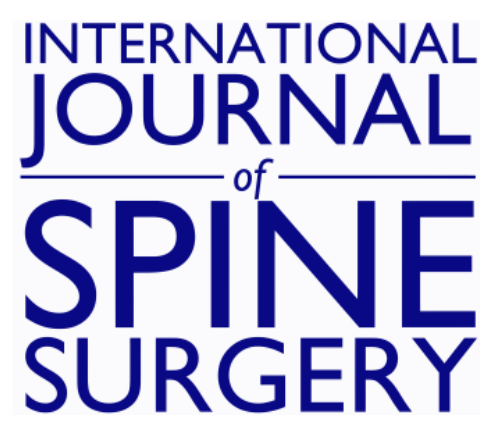

\title{
Recognizing the 2021 IJSS Peer Reviewers
}

Charles L. Branch, Jr

Int J Spine Surg published online 25 February 2022

http://ijssurgery.com/content/early/2022/02/22/8203

This information is current as of April 26, 2023.

Email Alerts Receive free email-alerts when new articles cite this article. Sign up at: http://ijssurgery.com/alerts 


\title{
Recognizing the 2021 IJSS Peer Reviewers
}

\author{
CHARLES L. BRANCH JR, MD ${ }^{1,2}$ \\ ${ }^{I}$ Editor in Chief, International Journal of Spine Surgery, Wheaton, IL, USA; ${ }^{2}$ Executive Director Spine Service Line, Atrium Health Wake Forest Baptist, Winston-Salem, \\ $N C, U S A$
}

The International Journal of Spine Surgery (IJSS) wishes to acknowledge and thank all of our peer reviewers in 2021. There were 448 manuscripts submitted and 953 reviews completed from an all-volunteer team of 250 reviewers representing 40 countries. This is a major contribution to our journal, and on behalf of the International Society for the Advancement of Spine Surgery Board of Directors and the IJSS Editorial Board, we thank you.

As with many other journals in disparate specialty areas, 2021 brought a record number of submissions to the IJSS. To process these submissions, the IJSS relied on a group of experts in spine surgery specializing in focused areas from pediatric spinal deformities to degenerative disc disease and everything in between.

Although the ongoing COVID-19 pandemic likely contributed to the influx of submissions across the globe, it also left our reviewers overwhelmed with review requests from not only the IJSS but other spine journals as well. Add to this the roller coaster of COVID19 vaccinations, infections, hospitalizations, and deaths as well as added protocols to mitigate the spread of the virus, and 2021 certainly brought its challenges. For all of these reasons, the IJSS is especially grateful to its talented team of expert reviewers.
The IJSS is also excited to announce the first annual peer reviewer recognition awards, which will be announced during the ISASS 22 Annual Meeting in the Bahamas, 1 June to 4 June 2022. We hope that you plan to attend this meeting and the special events we have planned for the IJSS team.

Again, thank you to all the reviewers for their contributions. To view the 2021 peer reviewer list, please visit https://www.ijssurgery.com/content/editorial-board-0.

Funding: The author received no financial support for the research, authorship, and/or publication of this article.

Disclosures: The author reports no financial disclosures or conflicts of interest related to this article.

Corresponding Author: Charles L. Branch Jr, Department of Neurosurgery, Atrium Health Wake Forest Baptist, 1 Medical Center Dr., Winston-Salem, NC 27157, USA; cbranch@ wakehealth.edu

Published 23 February 2022

This manuscript is generously published free of charge by ISASS, the International Society for the Advancement of Spine Surgery. Copyright (C) 2022 ISASS. To see more or order reprints or permissions, see http:// ijssurgery.com. 